\title{
Calcium Ion Activity in the Sick Neonate: Effect of Bicarbonate Administration and Exchange Transfusion
}

\author{
Ingeborg C. Radde ${ }^{[22]}$, David K. Parkinson, Bernd. Höfrken, Kwasi E. Appiait, \\ and William B. Haniey \\ l'epartment of Pediatrics, Lniversity of Toronto, and the Research Institute, 'The Hospital for Sick Children, 'Toronto, Cntario, Canada
}

\section{Extract}

Calcium ion activity was measured in plasma obtained by venous or arterial puncture using a calcium-selective flow-through electrode. Mean level of ionized calcium in umbilical venous plasma was $2.48 \pm 0.04 \mathrm{mEq} / \mathrm{liter}$. Within $30 \mathrm{hr}$ after birth, the values decreased in sick infants to $1.35 \pm 0.11 \mathrm{mEq} /$ liter. Total calcium concentra tions were in the normal adult range at birth $(5.20 \pm 0.08 \mathrm{mEq}$ /liter $)$, showing a subsequent decline to subnormal values $(3.47 \pm 0.28 \mathrm{mLq} /$ liter at age $30-40 \mathrm{hr})$. A calcium ion activity of less than $1.4 \mathrm{mEq} /$ liter was associated with total calcium level. at or below $3 \mathrm{mEq} /$ liter in $80 \%$ of patients. Symptoms and signs attributable to hypocalcemia (ionized fraction) or hypomagnesemia, or both, were found only in infants in whom plasma levels of both divalent cations were below the lower limit of normal. Administration of $\mathrm{NaHCO}_{3}$ for acidosis caused a slight rise in $\mathrm{pH}$ (from 7.20 to 7.28 $\mathrm{mEq} /$ liter) and a decrease in plasma calcium ion activity (from 1.68 to $1.51 \mathrm{mEq} /$ liter). During exchange transfusion with acid-citrate-dextrose (ACiD)-Tham buffered blood, calcium ion activity decreased significantly from $1.90 \pm 0.08$ to $1.20 \pm 0.09 \mathrm{mEq}$, liter, whereas total calcium levels increased consistently (from $4.22 \pm 0.13$ to $5.33 \pm$ $0.15 \mathrm{mEq} /$ liter).

\section{Speculation}

The temporary hypocalcemia, observed in sick newborn infants, may also occur in healthy newborns. It is thought to initiate normal calcium homcostasis by stimulating parathormone secretion and by bringing into play the two feedback mechanisms for calcitonin and parathormone secretion.

\section{Introduction}

One of the many adaptations that the newborn infant faces in the immediate neonatal period is the change from high to low calcium levels in the blood $[1,3,7,9$, 14]. With the development of a rapid and simple method for measuring calcium ion activity in small amounts of plasma by means of a calcium-selective elec- trode [12, 18], these changes can be assessed clirectly. Calculations of ionized calcium levels by the application of formulas among other deficiencies do not take into account the possibility of rapid changes in the internal milieu in the neonate. This applies particularly to parameters known to influence ionized calcium: $\mathrm{pH}$, protein, inorganic phosphate, and other calcium complexors. 
The problem of calcium abnormalities in the neowate is illustrated by the occurrence of significant hypocalcemia (plasma calcium levels $<3 \mathrm{mEq} /$ liter) in 93 of 312 sick infants admitted consecutively to the Neonatal Unit of The Hospital for Sick Children in Toronto during a 6-month period. Because of the magnitude of this problem, we unclertook a study of calcium ion activity in sick neonates in an attempt to correlate symptoms and signs of hypocalcemia with the calcium ion activity in the blood. This report contains results of three aspects of the studly chosen primarily to illustrate discrepancies between total and ionized calcium levels. The effects on calcium ion activity and total calcium level of age, treatment of acidosis with $\mathrm{NaHCO}_{3}$, and exchange transfusion were assessed.

\section{Materials ard Methods}

\section{Patients}

Sixty-two infants admitted to the Neonatal Unit with respiratory distress synclrome, with $\mathrm{Rh}$ or $\mathrm{ABO}$ incompatibility, or for olservation were selected for the studly. Blood was taken on admission and in 35 babics serially thereafter. The infants were examined particularly for signs of hypocalcemia (muscle twitching, conv'ulsions, irritability) and the reflex activity was assessed. The exact feeding history and medication administered were also recorded.

Patients with respiratory distress syndrome who required bicarbonate administration for acidosis had blood taken immediately before and $10 \mathrm{~min}$ after the administration of $\mathrm{NaHCO}_{3}$. The lose of $\mathrm{NaHCO}_{3}$ was calculated according to the following formula:

milliequivalents of $\mathrm{NaHCO} \mathrm{H}_{3}$ required

$$
\begin{aligned}
=\text { base deficit } & \text { (milliequivalents per liter) } \\
& \times \text { kilograms body weight } \times 0.3 .
\end{aligned}
$$

This dosage of $\mathrm{NaHCO}_{3}$ was given to produce half correction of the base deficit [13].

Exchange transfusion was carried out with acid-citrate-dextrose (ACD)-Tham buffered blood $(150 \mathrm{ml} / \mathrm{kg}$ body weight). Five milliliters $2 \%$ solution of calcium gluconate was given by push injection after each 100 $\mathrm{ml}$ blood. Blood for chemical determinations was obtained immediately before and 10 min after the transfusion.

\section{Procedures}

Blood was drawn anaerobically into plastic syringes containing I $\mathrm{mg}$ of a sodium heparin-soluble starch mixture (l:100) for each milliliter of blood. This amount of heparin $(1.6 \mathrm{U} / \mathrm{ml}$ blood $)$, shown by previous investigation [16] to have a negligible effect on the ionized calcium level $(P>0.1)$, facilitates the rapid processing of the blood. Blood was sampled either from umbilical vein catheter or by venous or arterial puncture. The $\mathrm{pH}$ of the blood was determined immediatcly; the syringe was then centrifuged for 5 min at $3000 \mathrm{rpm}$ and the plasma was removed anaerobically into a $1-\mathrm{ml}$ tuberculin syringe. Calcium ion activity was determined within $30 \mathrm{~min}$ after the blood was drawn, or the syringe was capped with Parafilm and frozen immediately. After thawing, the plasma in the syringe was briefly agitated on a Vortex mixer and the syringe was centrifuged. The calcium ion activity was determined by means of a flow-through calciumsclective electrocle [19]. The remaining plasma was analyzed for total calcium, magnesium, and protein levels and for inorganic phosphate concentrations. A minimum of $0.7 \mathrm{ml}$ blood was required for these determinations.

\section{Chemical Methods}

Total calcium and magnesium levels in plasma were determined by emission and atomic absorption flame spectrophotometry $[2,11]$, respectively. Inorganic phosphate levels were measured by an automatic adaptation of the Gomori proceclure [8]; total protein levels were measured by an automatic modification of the procedure of Lowry et al. [10], using human serum albumin as standard.

The stanclards for calcium ion activity measurements were prepared with $150 \mathrm{~mm} \mathrm{NaCl}$ by diluting the appropriate amounts of $\mathrm{CaCl}_{2}$ stock solution. Working standards also contained 3 clrops 1 x triethanolamine solution and $0.06 \mathrm{~g}$ trypsin per $100 \mathrm{ml}$. They were prepared fresh weekly and stored in the refrigerator when not used. Unkown samples were bracketed between two adjacent standards.

\section{Results}

\section{Serial Measurements}

Values obtained from 35 patients on whom serial measurements of ionized calcium were made are reported. Values following $\mathrm{NaHCO}_{3}$ treatment, exchange transfusion, or calcium administration were excluded. Figure 1 shows the pattern of Ca ion activity in these infants up to $120 \mathrm{hr}$ of age. During the first 5 hr of life, calcium ion activity was greater than that 
found in older children and adults, except in two infants whose mothers' calcium levels at delivery were reduced $(0.65$ and $1.30 \mathrm{mEq} /$ liter); these infants also showed relative hypocalcemia at the time of birth. Thereafter, ionized calcium levels decreased, with a minimum which was below the lower limit of normal occurring between 15 and $45 \mathrm{hr}$ of life. By the end of $120 \mathrm{hr}$, calcium ion activity in plasma had risen to values similar to those found in older children (Table I).

When total calcium levels were plotted in a similar fashion (Fig. 2), the pattern that emerges is of levels in the normal adult range at birth and a subsequent decline to subnormal values. A calcium ion activity of less than $1.4 \mathrm{mEq} /$ liter was associated with total calcium levels at or below $3 \mathrm{mLq} /$ liter in approximately $80 \%$ of patients, but dicl not correlate well in the remainder. The correlation coefficiont between total and ionic calcium was: $r=0.76, P<0.01$.

\section{Scrial Magnesium Levels}

Magnesium levels in cord blood were lower than those found in older children and adults (Table I). They then remained relatively constant cluring the first 5 days of life. Levels of plasma magnesium which by themselves might lead to symptoms (i.e., $<1.0$ $\mathrm{mEq} /$ liter) were observed only once; the simultaneous calcium ion activity in the plasma of this infant was

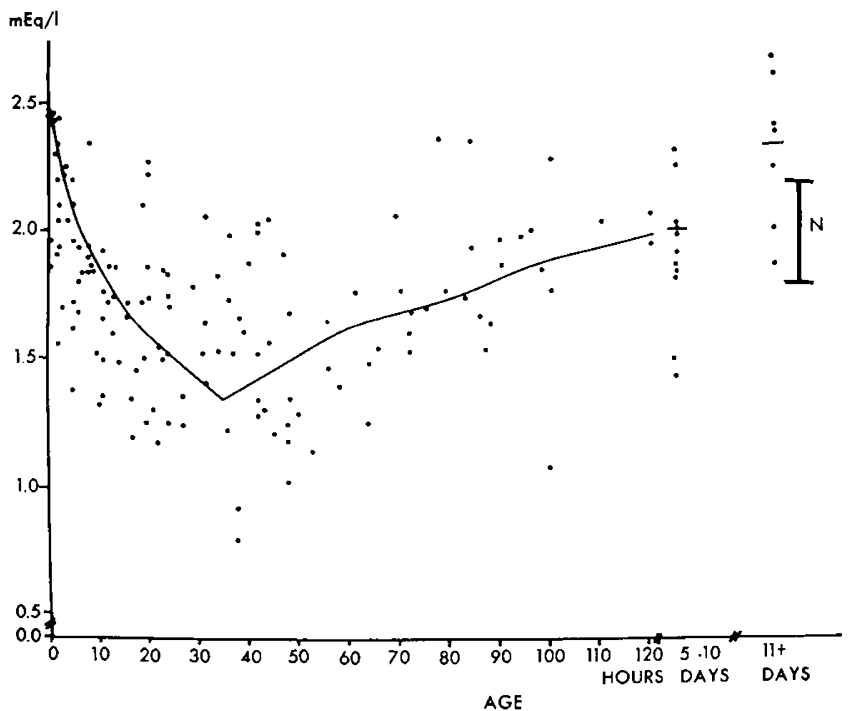

Fig. 1. Serial ionized calcium levels in plasma of sick ncwborn infants arranged according to age. The normal range in older children and adults is indicated by the bar labeled $x$. The line commects group means at $0,5,15,25,35,45,60,80$, and 100 hr of age.

Tuble $I$. Chemical variables studied in blood from sick newborn infants

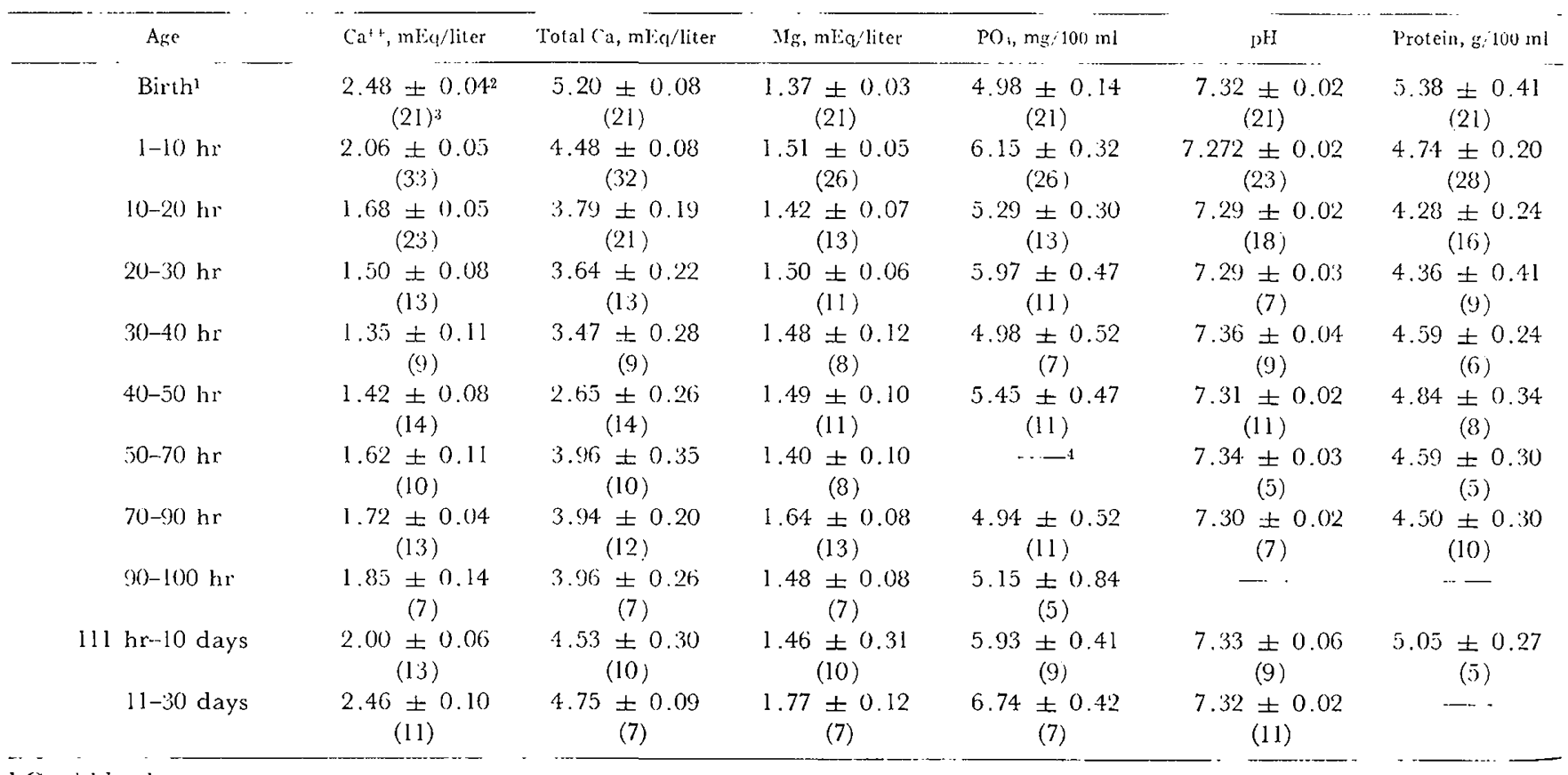

1 Cord blood.

${ }^{2}$ Mean $\pm \mathrm{SE}$.

${ }^{3}$ Number in parentheses: Number of observati.

4- : Insufficient number of observations. 


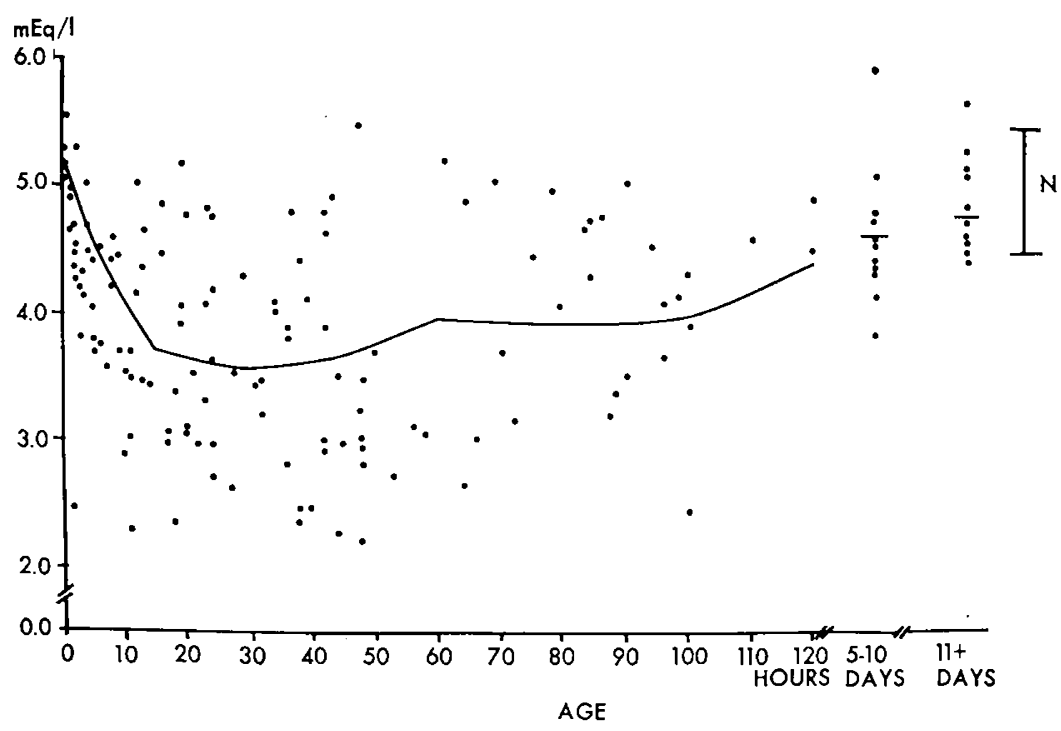

Fig. 2. Serial total calcium levels in plasma of sick newborn infants arranged according to age. The normal range in older children and adults is indicated by the bar labeled.$V$. The line connects group mean values at $0,5,15,25,35,45,60,80$, and $100 \mathrm{hr}$ of age.

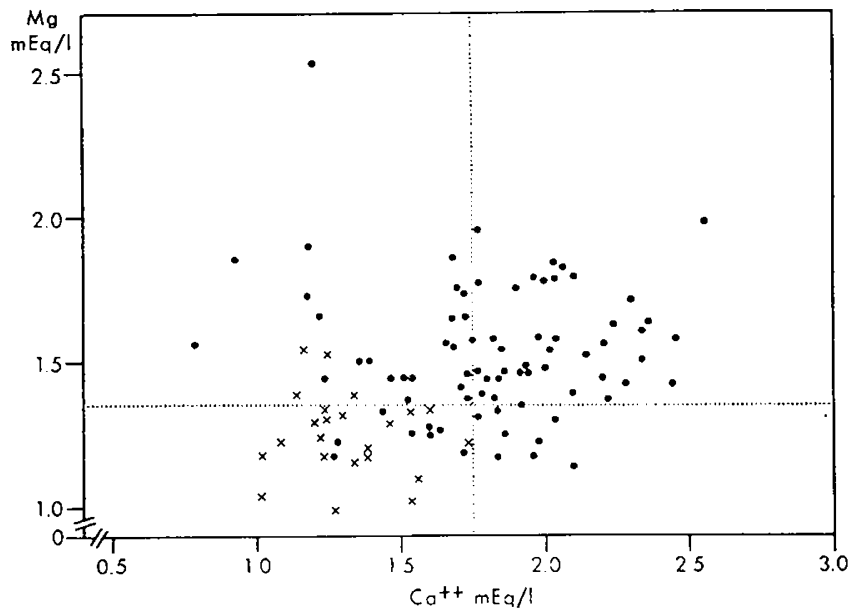

Fig. 3. Correlation between calcium ion activity and magnesium levels in newborn infants. The horizontal interrupted line indicates the lower limit of normal for magnesium values; the vertical interrupted line indicates the lower limit of normal for calcium ion activity. Crosses represent values for blood taken at the time of neuromuscular hyperimitability in the infants.

$1.3 \mathrm{mLq} /$ liter, and the infant showed muscle twitching.

Figure 3 depicts the relationship between ionized calcium and plasma magnesium levels. A positive correlation was observed which was highly significant $(r$ $=0.86 ; P<0.01)$. Symptoms and signs attributable to hypocalcemia (ionized fraction) or hypomagnesemia, or both, were found only in infants in whom both clivalent cations were below the lower limits of normal.

\section{Gestational Age and Minimal Values of Calcium Ion Activity}

When we correlated the gestational age of the baby (or the birth weight) with the ionized calcium values found, it became eviclent that premature or dysmature (small for gestational age) infants showed more severe and prolonged depression of calcium ion activity in their plasma than did full term infants. During the first $5 \mathrm{hr}$ of life, however, gestational age did not correlate well with calcium ion activity, the latter being high in all instances.

\section{Administration of $\mathrm{NaHCO}_{3}$}

Administration of bicarbonate was followed within 10 min by a slight rise in $\mathrm{pH}$ and a small but highly significant decrease in plasma $\mathrm{Ca}$ ion activity (Table II). Total calcium did not clecrease significantly. The decrease in ionized calcium did not correlate with the change, if any, in total calcium. Plasma magnesium levels also decreased $(P<0.05)$, whereas inorganic phosphate levels remained unchanged following bicarbonate administration. No symptoms or signs of hypocalcemia were observed at this time in infants receiving $\mathrm{NaHCO}_{3}$, although three values fell within the symptom range predicted by Figure 3 .

\section{Exchange Transfusion}

Results of 26 pre- and postexchange measurements were available for study. Two infants received two and one received three transfusions. Figure 4 depicts the 
Table II. Effect of bicarbonate adininistration on the plasma of sick newborn infants ${ }^{1}$

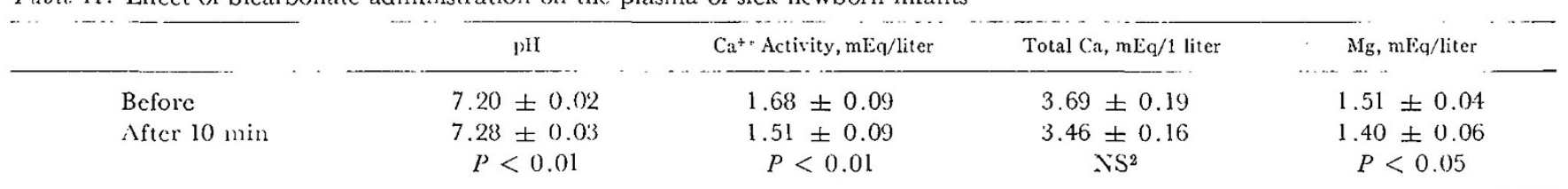

I Results given as mean \pm standard cror; $n=11$.

${ }^{2}$ NS: Not significant.

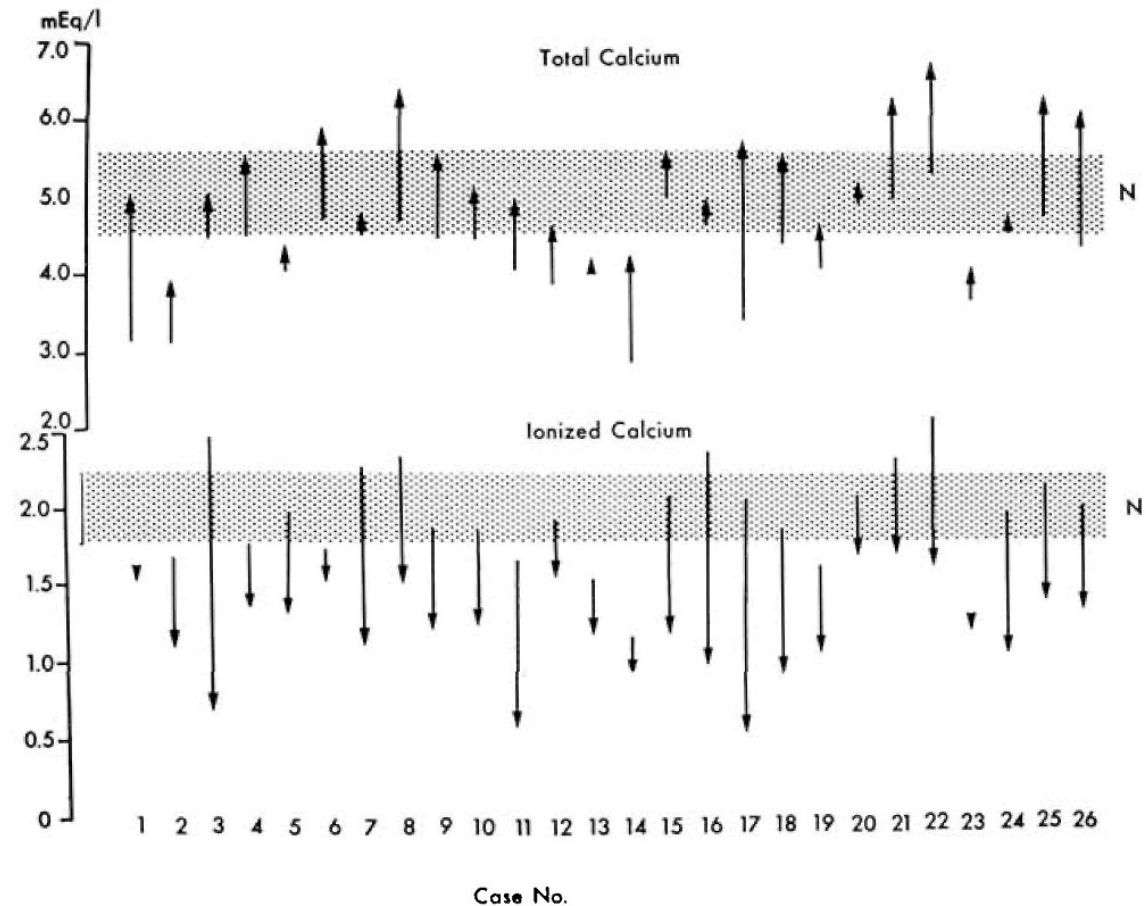

Fïg. 1. Calcium ion activity (lower panel) and total calcium levels (upper panel) in plasma taken before and after exchange transfusion. Shaded areas indicate the normal range for cach calcium value.

pre- and postexchange $(10 \mathrm{~min})$ levels of calcium ion activity and total calcium concentration. In cvery patient, there was a significant decrease in calcium ion activity in spite of the administration of the standard dose of calcium gluconate. Levels below $1.2 \mathrm{mEq} /$ liter were reached in eight patients, and were associated with muscle twitching or frank convulsions in four cases. Total calcium levels, on the other hand, increased consistently, in four instances into the frankly hypercalcemic range. The highest level observed was $6.75 \mathrm{mEq} /$ liter. The average blood $\mathrm{pH}$ did not change during transfusion (Table III). Plasma magnesium levels decreased significantly, but only to slightly below normal values. The changes in inorganic phosphate concentration were less clear-cut, and the difference between pre- and postexchange mean values was not statistically significant. Total protein levels in plasma did not change consistently during exchange transfusion.

\section{Discussion}

The development of a calcium-selective electrode has given us a helpful tool for correlating symptoms of neuromuscular hyperirritability with the concentration of the physiologically active fraction of plasma calcium in the sick newborn infant. As results are available within 20 min of drawing the blood, effective treatment of the significant hypocalcemia which occurs frequently in these neonates is facilitated. Although previous reports have indicated the existence of hypocalcemia in the neonatal period $[6,17]$, these changes were not serially related to symptoms nor was the discrepancy between total and ionized calcium fully 
Table III. Effect of exchange transfusion on the plasma of sick newborn infants ${ }^{1}$

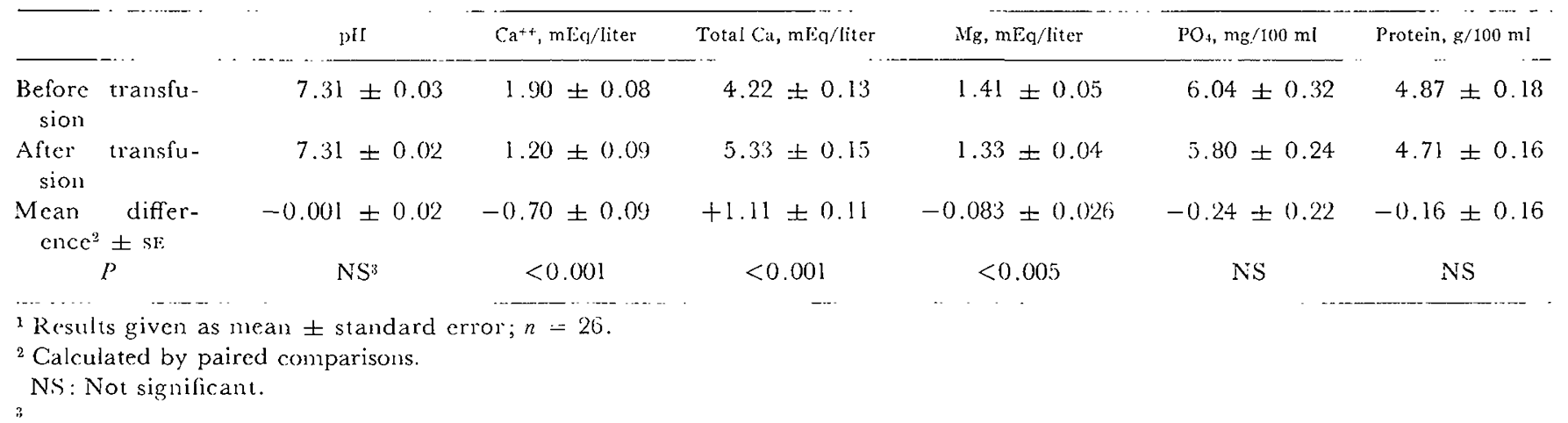

appreciated. Furthermore, significant depression of calcium ion activity occurs particularly in premature infants who, in addition to their hypocalcemia, have multiple biochemical abnormalities such as hypomagnesemia, hypoglycemia, and anoxia, each potentially capable of causing neuromuscular hyperirritability. In these infants, the primary cause of the hyperirritability can only be decided if the various biochemical abnormalities are assessed fully and scparately. The measurement of calcium ion activity will facilitate this assessment of one of the potentially fatal biochemical abnormalities in the neonatal period.

Yo define the time-course of hypocalcemia after the administration of $\mathrm{NaHCO}_{3}$, we had carried out parallel expeximents in experimental animals, aclministering equivalent amounts of bicarbonate, adjusted to body weight and to a base deficit of $10 \mathrm{mliq} / \mathrm{kg}$. These results, reported elsewhere [15], indicate that calcium ion activity indeed decreases rapidly (within $5 \mathrm{~min}$ ) with an increase in pFI in the rats. We suggest that similar rapid changes occur in infants whose acidosis is corrected with sodium bicarbonate, and one should be careful to avoid overcorrection of the acidosis, particularly before the end of $100 \mathrm{hr}$ of age. Before this time, calcium ion activity is still low and may be further decreased by any increase in pH, which may result from treatment of the respiratory distress syndrome with sodium bicarbonate.

The practice of using ACD blood with adcled calcium gluconate for exchange transfusion leads to two undesirable consequences. First, the abrupt clecrease in calcium ion activity may exacerbate the poor metabolic state of an often seriously ill infant. It secms that the administered amount of calcium gluconate furnishes an insufficient number of calcium ions to neutralize the citrate in the transfused blood, which forms nonionized complexes with calcium. Calcium gluconate by itself is not fully ionized at pH 7.40. Further- more, the citrate in the transfused blood may not be metabolized efficiently by the neonate, especially when he is anoxic, premature, and perhaps has reduced liver function. 'This may lead to a dangerous reduction in calcium ion activity in the blood, such as that seen in later life under exceptional circumstances such as ardiopulmonary bypass operations.

The second serious consequence of the administration of calcium gluconate during exchange transfusion is the significant hypercalcemia which occured in one-thirel of the infants examined. Glomerular filtration rate in the newborn is much less than in older children [4]. Because the concentrating ability of the kidney is also reduced [5], any increase in calcium levels in plasma would require increased amounts of water for efficient excretion of the calcium complex. This may upset the already inefficient mechanism for homeostasis in the sick newborm infant. Stuclies are in progress to evaluate the suitability of using $\mathrm{CaCl}_{2}$ during exchange transfusion.

\section{Summary}

'True ionized calcium levels could not be measured in small amounts of plasma until the recent development of a Ca $\cdots$-specific electrode made this possible. Thus, the incidence and magnitude of hypocalcemia in the neonatal period has not been appreciated fully. We found that, although total calcium levels in cord blood are generally in the normal adult range, calcium ion activity is high. In the sick neonate, calcium ion activity and, usually, total calcium levels decreased, reaching a minimum between 30 and $40 \mathrm{hr}$ of age. Acutc changes in acicl-base status (e.g., hypo- and hyperventilation and $\mathrm{NaHCO}_{3}$ administration in the treatment of acidosis) lead to rapid changes in calcium ion activity, whereas total calcium concentration may remain unchanged. During exchange transfusion with ACD- 
Tham buffered blood, calcium ion activity clecreases profoundly, whereas total calcium levels were found to be increased because of the routine administration of calcium gluconate. These results are evidence for the frequently observed dissociation between total calcium and ionized calcium levels in the sick neonate.

\section{References and Notes}

1. ACHIRIA, P. T., ANo PAYNE, W. W.: Blood chemistry of normal full-tcrm infants in the first 48 hours of life. Arch. Dis. Childhood, t0: 430 (1965).

2. Aı.ock, N., MAcINTrke, I., A.No R.Ine, l.: The determination of magnesium in biological fluids and tissues by' flame spectrophotometry. J. Clin. Pathol, 13:506 (1960).

3. ANuersch, M., ANI Oberst, F. W.: Filterable serum calcium in late pregnancy and parturient women and newborn. J. Clin. Invest., 15: 131 (1936).

4. BARNETT. II. I.: Renal physiology in infants and children. I. Method for estimation of glomerular filtration rate. Proc. Soc. Exp. Biol. Med., 14: 654 (1940).

5. (an.cagio, P. L., Rebin, M. I., ani) Wemtradb, D). H.: Studies on the renal concentrating and diluting mechanism in the premature infant. J. Cin. Invest., 33: 91 (1954).

(i. Dithoria-PApadopolios, M., BatTagla, I. C., BreNs, P. D., ANo Mescma, G.: Total procein-bound, and ultra-filcerable calcium in matcrnal and fetal plasma. Amer. J. Physiol., 213: $363(1967)$.

7. DORMANDY, 'T. L., A.ND Browa, R.: The plasma calcium and plasma magnesium response to standard metabolic loads in infants. In: D. Barltrop and W. I. Burland: Mineral Metabolism in Pacdiatuics, p. 31 (Blackwell Scientific Publications, Oxford, 1969).

8. Gomort, G.: $A$ modification of the colorimetric phosphorus determination for use with the photoelectric colorimeter. J. Lab. Clin. Med., 27 : 955 (1942).

9. Honfanurr, L., Rosinbero, 'T. F., AND On, W.: Calcium and phosphorus homeostasis on the first day of life. Biol. Viconatorum, 15:49 (1970).

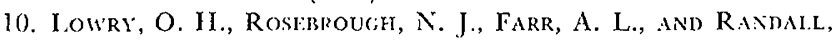

R. J.: Protein measurement with the Folin Phenol reagent. J. Biol. Chem., 193: 265 (1951).

11. MaClNtyre, I.: Iilame photomety. Advan. Clin. Chem., 4: 1 (1961).

12. Moore, E. W': Ionizcd calcium in normal serum, ultrafiltrates and whole blood determined by ion-exchange electrodes. J. Clin. Invest., f9: 318 (1970).

13. Nit.son, N. M., A.ip Rir.gel, K. P.: A schematic approach to aciel-base therapy in the newborn. Pediatrics, +3: 821 (1969).

14. Pacpe, J., Colln, J., Polmis, E., and Leloni, M.: Some physiological variations of blood calcium level in mothers during labor, in corcl and newbom infants. Biol. Neonatorum, 3: $35 \%(1961)$.

15. RADin:, I. C., HörFkF, B., ANd PARKinson, D. K.: Eflects of altcrations of blood $\mathrm{p} \mathrm{H}$ on calcium ion activity in rat plasma. (lin. Orthop. Related Res., $78: 30$ (1971).

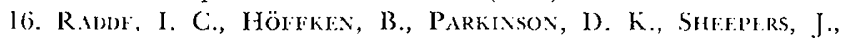
An LxckHan, A.: Practical aspects of a measurement tech. nique for calcium ion activity in plasma. Clin. (hem., it: $1002(1971)$.

17. Rosenkranz, A.: Der Serumcalziumspiegel beim Frühgeborenen in den ersten teloenstagen. Paediat. Paedol., 2: 367 (1960).

18. Sachs, C., Bourdeal, A.-M., ANd Balsax, S.: Détermination clu calcium ionizé dans le serum avec une electrode specifípuc a membrane liquidc. Ann. Biol. Clin., 2: 487 (1969).

19. Model 99-20, Orion Research Corporation, Inc., Cambridge, Mass.

20. The authors wish to acknowledge the helpful atrice of Dr. P. Swyer, M.A., M.B. (Cantals.), M.R.C.P. (Concl.), in whose Neonatal Lnit the clinical part of the study was carried out; the competent technical assistance of Mrs. J. Sheepers, R. T., and Miss A. I.uckham, R. T., and the enthusiastic help of Messis. Peter Storms, B.Sc., and D. McLean.

21. Supported in part by Grant no. MA-1797 from the Medical Research Council of Canada.

22. Requests for reprints should be addressed to: INcerrorg C. RADDE, M.D., Rescarch Institute, The Hospital for Sick Children, 555 University Arenuc, Toronto 2, Ontario, Canada. 23. Accepted for publication April 15, 1971 . 